\title{
Ownership Structure, Corporate Governance, and Corporate Social Responsibility with Financial Performance as Intervening
}

\author{
Anang Ariful Habib ${ }^{1}$, Muhammad Miqdad ${ }^{2}$, Yosefa Sayekti ${ }^{3}$ \\ ${ }^{1}$ Accounting Magister Program, Faculty of Economics and Business, Universitas Jember, Indonesia \\ ${ }^{23}$ Department of Accounting, Faculty of Economics and Business, Universitas Jember, Indonesia \\ Email: anang.ariful@gmail.com
}

A R T I C L E INFO

Date of entry:

05 July 2020

Revision Date:

18 August 2020

Date Received:

09 September 2020

\begin{abstract}
A B S T R A C T
Corporate Social Responsibility (CSR) programs are carried out by entities in the hope of getting legitimacy and positive values from the community. So, companies can survive and develop, and it can increase profitability in the future. CSR has a relationship with Good Corporate Governance (GCG), Ownership Structure, and Financial Performance. This research aims to analyze the effect of the ownership structure and good corporate governance on corporate social responsibility disclosure through finance performance. The interpretation technique of the sample that is used in this research is purposive sampling. That is the manufacturing company listed on the IDX period 2017 - 2019. The data analysis method that is used is the path analysis. The resulting research is the managerial ownership influence at finance performance significantly. Institutional ownership is not influenced by finance performance. The foreign ownership influence at finance performance significantly. The measure of commissioner council influence at finance performance significantly. The Audit Committee has a positive effect on financial performance. Managerial ownership has a positive effect on CSR. Institutional ownership is no significant effect on CSR. Foreign ownership has a significant effect on CSR. The measure of Commissioners council has a significant effect on CSR. The Audit Committee has a significant effect on CSR. Financial performance has a significant effect on CSR.
\end{abstract}

Keywords: Ownership Structure, GCG, Financial Performance, CSR.

Cite this as: Habib, A. A., Miqdad, M., Sayekti, Y. (2020). Ownership Structure, Corporate Governance, and Corporate Social Responsibility with Financial Performance as Intervening. Wiga : Jurnal Penelitian Imu Ekonomi, 10(2), 118-131. https://doi.org/10.30741/wiga.v10i2.565

\section{INTRODUCTION}

Environmental damage often becomes the main topic of discussion in the world currently, besides the other important topics such as economic, social, political, and health issues. It happened because this time, there is a lot of severe environmental damage, such as deforestation, the 
ecosystem damage in the sea, and polluted rivers by hazardous waste. This environmental damage almost happened in the entire of the world and included in Indonesia. The fact Indonesia is famous for its wealth and abundant natural resources. The handling of environmental damage is the responsibility of all Indonesia societies, including the government and companies. The company should not only take the company's profit but also must fulfill the needs of the concerned parties (shareholders, managers, and employees) and maintain the norms in the surrounding. A manufacturing company is a company that deals with natural resources and the surrounding environment in conducting the operation. Therefore manufacturing companies should be able to provide social and environmental responsibility (Eriandani, 2013).

Corporate responsibility must be based on triple bottom lines, namely financial, social, and environmental, not only on a single bottom line, namely corporate value, which is described in the company's financial condition only. Corporate Social Responsibility (CSR) is an idea of corporate social responsibility. With this, the company is able to grow in a sustainable manner (sustainable) because only guaranteeing its financial condition is not enough. If the company pays attention to the social and environmental dimensions, it will guarantee the company's sustainability. For this reason, it is necessary to have a mandatory CSR in nature from the initial CSR that was only voluntary (Riswari, 2012).

Indonesia's disclosure of CSR is regulated in the Law on Limited Liability Companies, Number 40 of 2007, Article 66 clause 2. The Financial Services Authority (OJK) has also issued rules requiring public companies to disclose CSR activities in the annual report. The regulation emphasized on the company received a positive response from managers so that the number of companies performing social responsibility disclosure in its annual report is increasing, and the number and type of disclosure in social responsibility activities are increasing (Sayekti and Wondabio 2007).

Based on the data from the Environmental ministry, showed that there were ten companies with much waste in Indonesia in 2019. Generally, these companies come from the metal and mineral mining sector. This is why companies must have an integrated concept of CSR. The company's attention to the environment and society is called CSR that has a wide meaning. But, shortly, the company's attention can be known by the action of the company to make a balance between stakeholders. The following is data on the ten companies with the most waste in Indonesia in 2019:

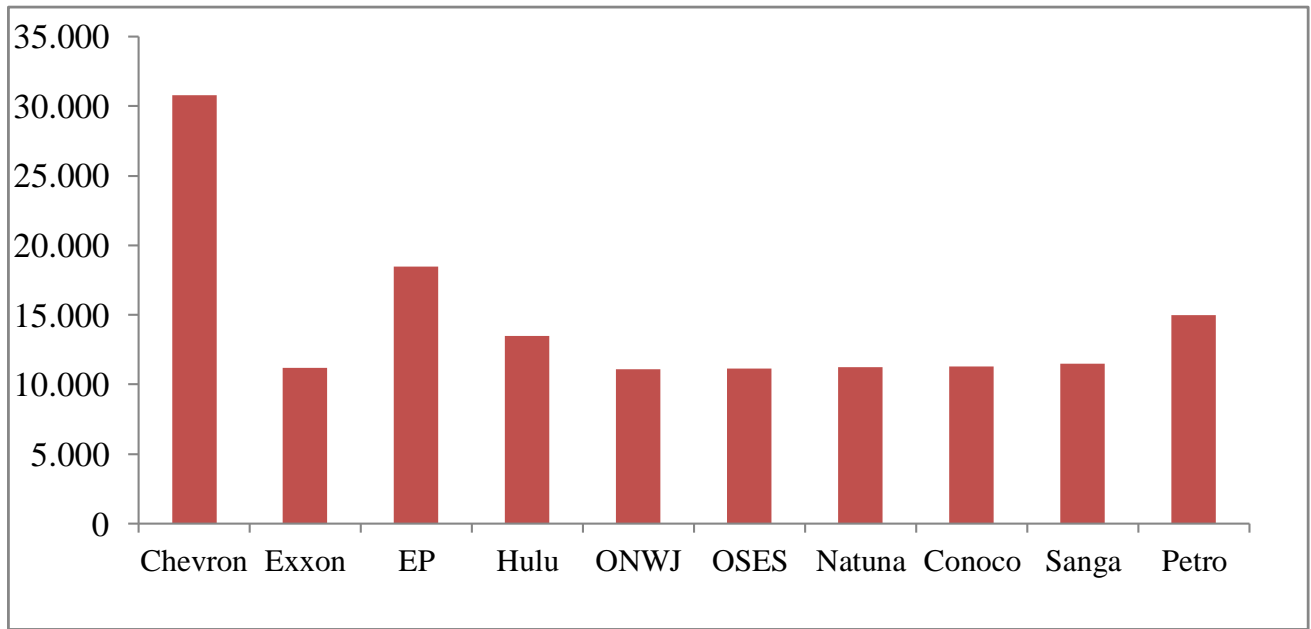

Source: Ministry of Environment 2020

The composition of the number of shares owned by the company with the number of shares owned by investors resulted in the birth of the term company ownership structure. A company can be 
owned individually, the wider community, government, foreign parties, or people in the company (managerial). The difference in the contribution proportion owned by investors can affect the level of completeness of the disclosure by the company. The more parties who need information about the company, the more detailed disclosures are made by the company (Wati, 2012).

The relationship between the Good Corporate Governance structure with CSR disclosure can be explained through the legitimacy theory. In this study, the use of legitimacy theory has implications that CSR programs are carried out by entities in the hope of getting legitimacy and positive values from the community. So, companies can survive and develop, and it can increase profitability in the future. Increased profitability on the entity in the rating form of return on equity can be realized if the management carries out the company's operations well without deceitful that might be done by the management.

The importance of financial ratios for investors is to analyze the condition of the company's financial performance (Brealey et al., 2007; Fahmi, 2014). The discussion regarding the company's financial performance is closely related to financial ratios. One is that it is often used to calculate the amount of profitability is Return on Assets (ROA). ROA analysis is used to measure and show the company's ability to use its assets to generate actual profits for the company. The higher the financial performance, the more likely the company will perform CSR disclosure properly.

The annual report of PT. Prasidha Aneka Niaga Tbk. Disclose CSR activities in the health, social, and religious fields. Besides that, in the same year, PT. Ultrajaya Milk Industry Tbk. Discloses various CSR activities in the environmental, social, cultural, religious, and educational fields. From the different CSR activities carried out by the two companies, it shows that there are wide differences regarding the CSR disclosure activities carried out by each manufacturing sub-sector company (Ilmi, 2017).

The difference between this study and previous research is the addition of an intervening variable in financial performance. Financial performance is a description of the economic results that a company can achieve at a certain time through its activities. These activities are recorded and summarized into information that can be used as a medium to report the condition and position of the company to interested parties, especially creditors, investors, and the company's management itself (Aminatuzzahra, 2010). The research done by Listyaningsih (2018) shows that managerial ownership, institutional ownership, ownership have a significant effect on disclosure of CSR, while the independent board of commissioners, the audit committee, has no effect on disclosure of CSR.

Manufacturing companies listed on the Indonesia Stock Exchange (IDX) for the 2017-2019 period are the objects of this research because of manufacturing industries is one of the largest in Indonesia, so that it has a very large impact on economic development. On the other hand, the growth of the manufacturing industry has a negative effect on the environment, namely the increasing amount of industrial waste, which has the potential to cause environmental pollution.

Legitimacy theory focuses on the interaction between companies and the community. Community legitimacy is a factor which considered important for companies to continue to survive and develop. It can be used as a vehicle for constructing a company's strategies, especially those related to efforts to position themselves in the midst of an increasingly developing and advanced community environment (Hadi, 2011: 87). Legitimacy is expected to encourage the company's going concerned by bringing benefits and potential resources to the company.

A contract between the manager (agent) and the investor (principal) is an agency relationship described according to agency theory. Agency costs arise due to a conflict of interest between the owner and the agent because the agent may not always act in the interests of the principal (Hamdani, 2016: 30). The opinion of this theory states that the separation between ownership and 
management of the company can cause agency problems. The authority of the manager (manager) given by the owner of the company is used to manage the running of the company, such as managing funds and making other company decisions for and on behalf of the company owner. Managers do not act on the interests of the owners because of conflict interests. In agency theory, managers are asked to optimize the rate of return for shareholders and because share ownership is fully owned by shareholders (Hamdani, 2016: 30).

Ghozali \& Chariri (2014) stated that the company's survival depends on its stakeholder, and the support must be sought as a form of company activity. The social disclosure is considered to play a role as a medium of communication between companies and stakeholders, so that the greater the company's efforts to adapt, the more powerful the stakeholders will be. Stakeholder theory reflects the actions of company management in an effort to produce reports according to the willingness and power of different stakeholder groups. The company's ability to bridge the use of limited economic resources (labor and capital), the ability to regulate the company and influence the consumption of products produced by the company, and access to influential media, are a form of power (Ghozali \& Chariri, 2014).

The Effect of Managerial Ownership with Financial Performance. According to agency theory, the emergence of agency conflict is due to differences in interests between managers and shareholders. The conflict of interest between managers and shareholders gets bigger when managerial ownership in the company gets smaller. Conversely, the greater the manager's ownership, the company manager, will improve the company's image by disclosing corporate social responsibility (Gray et al., 1995). The research done by Hermiyeti (2016) shows a positive influence between managerial ownership and financial performance. This is in line with the research of Ilmi (2017), which proves that there is an influence between managerial ownership and financial performance. It indicates that managerial ownership has an important function in financial performance; it can be seen from the two research. $\mathrm{H}_{1}$ : Managerial ownership has an influence on financial performance.

The Effect of Institutional Ownership on Financial Performance. Stakeholder theory reflects the action of company management in an effort to produce reports according to the willingness and power of different stakeholder groups. According to Ghozali \& Chariri (2014), the power can be in the form of a company's ability to bridge the use of limited economic resources (labor and capital), the ability to manage companies and influence consumption of goods and services produced by companies, and access to influential media. The research by Hermiyeti (2016) and Ilmi (2017) shows that there is a significant effect of institutional ownership on financial performance. The encouragement from the institutional owner for monitoring performance management will be more optimal. With the existence of institutional shareholders, it is considered capable of making an effective monitoring system in every decision taken by managers, so that management in making decisions will be more careful. $\mathrm{H}_{2}$ : Institutional ownership has an influence on financial performance.

The Effect of Foreign Ownership on Financial Performance. In agency theory, managers are supportive of increasing the level of benefits for shareholders and because share ownership is owned by shareholders (Hamdani, 2016: 30). The process of ordering a good corporate governance system that plays a role in bridging the separation of interests between owners and managers in carrying out duties and authority in a company has a relationship with agency theory. the implementation of corporate governance obtains a new style from agency theory, where company founders can make proportional agreements, namely between shareholders and agents (Raharjo, 2013). The research results from Ilmi (2017) prove that there is a significant effect of foreign ownership on financial performance. The potential for foreign ownership can improve the competitive climate between companies. This is a positive thing because, with increasing competition, the company will try its best to survive in this competition. Therefore, companies 
need to improve corporate governance. $\mathrm{H}_{3}$ : Foreign ownership has an influence on financial performance.

The Effect of Board Commissioners Size with Financial Performance. A contract between the manager (agent) and the investor (principal) is an agency relationship described according to agency theory. In the concept of agency theory, managers (agents) are asked to maximize shareholder returns and because share ownership is fully owned by shareholders (Hamdani, 2016: 30). Agency costs arise as a result of a conflict of interest between the owner and the agent because the agent may not always act in the interests of the principal (Hamdani, 2016: 30). Supervision of company management is the duty of the board of commissioners. According to the National Committee for Governance Policy (KNKG), they are regulating and monitoring the highest internal. Control mechanism and collectively responsible for supervising and providing input to the board of directors and ensuring that the company implements GCG is the authority of the board commissioners size (Heriyanto, 2015). This indicates that the board of commissioners size plays an important role for investors, creditors, and the government in evaluating companies. Companies tend to disclose information extensively in their social responsibility reports regarding their ability to maintain business viability. Research by Khoirudin (2013) states that the board. Commissioner size has an influence on financial performance. Widyati (2013) also states that there is an influence between the size of the board of commissioners on financial performance. $\mathrm{H}_{4}$ : The board commissioner size has an influence on financial performance.

The Effect of the Audit Committee on Financial Performance. Based on agency theory, to ensure the agent's responsibility, the principal, as the owner of the company, always tries to find information and provide intensive. This information is obtained from the audit committee, where the audit committee is responsible for financial reporting, supervision, and corporate governance. Agency costs will be lower if the audit committee monitors closely. Previous research conducted by Hermiyeti (2016) proved that the audit committee has an influence on financial performance. The role of the audit committee is a GCG mechanism, thus affecting CSR disclosure in the annual report. $\mathrm{H}_{5}$ : The audit committee has an influence on financial performance.

The Effect of Managerial Ownership with CSR. Agency theory states that differentiating ownership from company management can give rise to agency problems. The authority of the manager (manager) given by the owner of the company is used to manage the running of the company, such as managing funds and making other company decisions for and on behalf of the company owner. Managers do not act in the interests of the owner because there are different interests. In agency theory, managers are asked to maximize shareholder returns and because share ownership is fully owned by shareholders (Hamdani, 2016: 30). The research was done by Listyaningsih (2018) research shows that there is an influence between managerial ownership on CSR. Managerial ownership can reduce agency problems because the manager's performance will be better, along with the increase in share ownership in the company. Managers will try their best to improve company performance. Based on these results, it indicates that managerial ownership has an important role in the disclosure of CSR. $\mathrm{H}_{6}$ : Managerial ownership has an influence on Corporate Social Responsibility (CSR)

The Effect of Institutional Ownership with CSR. The use of legitimacy theory implies that CSR programs are carried out by manufacturing companies in the hope of getting positive values and getting legitimacy from the community. This means that if the company gets legitimacy from the community, then the company can continue to survive and continue to grow and get benefits in the future. Companies with large institutional ownership are more capable of monitoring management performance. Power and experience as well as responsibilities of institutional owners in implementing GCG principles in order to protect the rights and interests of all investors, so that companies communicate transparently (Matoussi \& Chakroun, 2008). Thus, the quality and quantity of voluntary disclosure increase along with institutional ownership. This means that CSR disclosures increase due to stimulus from institutional shareholders. CSR is usually seen as a tool 
to enhance a company's reputation and generate goodwill among customers. The results of Listyaningsih's (2018) research show the influence of institutional ownership on CSR disclosure. This is in line with Sari (2013), who proved the influence of institutional ownership on the level of CSR disclosure. Based on this research, it indicates that institutional ownership has an important role in CSR disclosure. $\mathrm{H}_{7}$ : Institutional ownership has an influence on Corporate Social Responsibility (CSR).

The Effect of Foreign Ownership with CSR. The implementation of GCG in which company founders can make a proportional agreement between the principal (shareholders) and the agent (directors), this is a new feature of agency theory. GCG is one of the key components in increasing economic efficiency, which includes a series of relationships and complete information disclosures between company management, the board of commissioners, and investors, as well as other stakeholders (Raharjo, 2013). Foreign ownership is the shares owned by foreign parties against company shares in Indonesia. Foreign ownership in the company is a party with an insight into the disclosure of corporate social responsibility. This is evident from previous research, which states that from an environmental aspect, companies in Indonesia are better than national companies. This means that companies with ownership will reveal greater social responsibility because they have larger funds to fund social and environmental activities. This makes multinational companies begin to change their behavior in serving the legitimacy and reputation of the company (Fauzi \& Eleven, 2008). $\mathrm{H}_{8}$ : Foreign ownership has an influence on Corporate Social Responsibility (CSR).

The Effect of The Board Commissioners Size with CSR. The board of commissioners functions as a management supervisor. According to the National Committee for Governance Policy (KNKG), it is regulating and monitoring the highest internal control mechanism and collectively. Responsible for supervising and providing suggestions to the board of directors and ensuring that the company implements GCG; this is the authority of the board of commissioners (Heriyanto, 2015). Management is required to disclose CSR information widely in order to realize accountability; this is the influence of the board of commissioners. In accordance with the opinion of Heriyanto (2015), which states that based on stakeholder theory, the board of commissioners functions as an accountability mechanism that plays a role in ensuring that the company must also fulfill the interests of stakeholders, not only fulfill the interests of shareholders. The results of Khoirudin (2013) 's research suggest that the board of commissioners size has an effect on CSR disclosure. Other research from Nurman and Miranti (2013) proves that the board of commissioners size affects CSR disclosure. $\mathrm{H}_{9}$ : The board of commissioners size has an influence on CSR.

The Effect of the Audit Committee with CSR. The principal will try to find information and provide intensive efforts to ensure the agent's responsibility to the company it owns; this is in accordance with agency theory. Principals appoint an audit committee in need of financial statement information, corporate governance, and corporate oversight. The level of business results obtained by the agent can be measured based on the information obtained by the principal. The tight supervision carried out by the audit committee can reduce agency costs. The results of Fauzyyah's (2018) research show that the audit committee has an influence on CSR disclosure. The task of the audit committee is as one of the corporate governance systems so that it can influence CSR disclosure. $\mathrm{H}_{10}$ : The audit committee has an influence on CSR.

The Influence of Financial Performance with CSR. Profit margin, return on assets (ROA), return on equity (ROE), and dividend payout ratio (payout ratio). This analysis is a method used to measure the level of company profitability. (Kasmir, 2012). If the value of profitability is high, then the possibility of CSR disclosure will also be better. A company is an entity that must be able to share benefits for its stakeholders, not only doing business for personal gain; this is in accordance with stakeholder theory. Profitability is measured using ROA obtained from the comprehensive income statement during the period in the annual report. Previous research on the effect of profitability on social reporting disclosure has had mixed results. The results of Nurkhin's 
(2010) 's research prove that profitability has an effect on CSR. The economic performance of a company is synonymous with profitability. The company value will increase along with the high economic performance of the company. One of the efforts to attract investors is by showing high company value. The companies which are increasingly profitable will try to attract investors' attention by showing the breadth of information disclosed in social responsibility reports. $\mathrm{H}_{11}$ : Financial performance has an influence on CSR.

CSR was calculated based on the total net income of the company and divided by 91 indicators based on GRI 2016. The measurement is based on the disclosure index of each company, which is calculated by dividing the company's net income with the number of items the company is expected to disclose. The checklist lists the items of corporate social responsibility disclosure measured using a dichotomy approach using a dummy variable, namely a score of 0 if the company does not disclose social responsibility in the research instrumentation and a score of 1 if the company discloses social responsibility on the research instrument. Next, the scores of each item are totaled for each company. According to Hadi (2018), the calculation formulation of social responsibility disclosure is as follows: CSRDIJ $=\sum \mathrm{Xij} / \mathrm{nj}^{*} 100 \%$. Information, CSRDIj: CSR Index for company $\mathrm{j}$ in the year $\mathrm{i}, \mathrm{Nj}$ : Number of CSR criteria for company $\mathrm{j}, \mathrm{NJ} \leq 91$, Xij: The number of items disclosed by company $\mathrm{j}$ in the year $\mathrm{i}$

The ratio between the number of shares owned by managerial parties to the number of shares outstanding in the company; this is a formula for measuring managerial ownership (Sartono, 2010). Managerial ownership = Total shares owned by management $/$ The number of shares outstanding* $100 \%$. The institution is divided by the number of shares taken; this is a way of measuring institutional ownership (Sartono, 2010). The formula for calculating managerial ownership is as follows: Institutional ownership = Total shares owned by institution/number of shares outstanding* $100 \%$. Foreign ownership in this study uses the percentage of foreign share ownership seen in the company's annual report. Suppose a company has more than one foreign owner who owns the company's shares (Sissandhy \& Sudarno, 2014. The formula for calculating managerial ownership is as follows: Foreign ownership = Total shares owned by foreigns/ number of shares outstanding* $100 \%$.

The way to determine the size of the board of commissioners is the number of commissioners the company owns and is included in the annual report (Khoirudin, 2013), with the following formula: The Board of Commissioners Size $=$ The total number of members of the board of commissioners. Measuring the audit committee by counting the number of audit committee members owned by the company and recorded in the annual report (Ratnasari, 2011). with the following formula: Audit committee $=$ The number of all members of the audit committee The value of company profitability in this study is measured using ROA. The ROA ratio can be calculated by dividing the value of net income plus interest by total assets (total assets). The following is the formula used to measure Return on Assets (Kasmir, 2012): Return on Asset = Net profit + Interest/ Average total assets

\section{METHOD}

A quantitative approach is used in this research. All manufacturing companies listed on the IDX are the population of this research. The sample is part of the population element (Indriantoro and Supomo, 2014). The samples are manufacturing companies that have been listed.on the IDX for the period 2017-2019. Data analysis used the path analysis method. The classical assumption test is used to test the feasibility of the regression model, which will then be used for the hypothesis in the study. The data analysis process in this research was carried out with the Statistics Product and Service Solution (SPSS) program. 
In this study, there are several companies that have to be excluded from the sample because they do not report data on their financial statements fully, such as institutional ownership and foreign ownership data, it caused the limited sample of companies in number. Based on the qualification data above, there are 17 companies that can be used as research samples during the period 2017 2019. So, the number of samples is 51 research data for three years of observation.

\section{RESULTS AND DISCUSSION}

Descriptive statistics are used to determine the description of data, which can be seen from the average (mean), maximum and minimum values, and the standard deviation of the research variables. The following shows the results of variable descriptive statistical data processing.

Table 1. Descriptive Statistics Results

\begin{tabular}{lrrrrr}
\hline \multicolumn{1}{c}{ Research variable } & N & \multicolumn{1}{c}{ Min } & \multicolumn{1}{c}{ Max } & Mean & \multicolumn{1}{c}{$\begin{array}{c}\text { Standard } \\
\text { Deviation }\end{array}$} \\
\hline Managerial Ownership (X1) & 51 & 0,01 & 0,84 & 0,07 & 0,0139 \\
Institutional Ownership (X2) & 51 & 0,01 & 0,64 & 0,29 & 0,1669 \\
Foreign Ownership (X3) & 51 & 0,06 & 0,87 & 0,46 & 0,2180 \\
Board of Commissioners Size (X4) & 51 & 2 & 6 & 3,8 & 1,0201 \\
Audit Committee (X5) & 51 & 2 & 5 & 2,80 & 0,8004 \\
Financial Performance (Y1) & 51 & 0,01 & 0,71 & 0,07 & 0,0127 \\
Corporate Social Responsibility (Y, Y $\left._{2}\right)$ & 51 & 0,09 & 0,37 & 0,17 & 0,0572 \\
\hline
\end{tabular}

Source: Output SPSS, 2020

The classic assumption test used in this study is (1). Data normality test, it is known that the probability or significance value of the research variables in the two pathways is greater than 0.05 . So, it can be stated that the data in this study are normally distributed; (2). Multicollinearity Test, Based. On the results of the Collinearity Statistics analysis, it is known that the model does not occur multicollinearity. This is indicated by a VIF value $<10$ and tolerance $>0.1$; (3). Heteroscedasticity test, it is known that the significance value of each variable is greater than 0.05 so that from these results, it can be seen that there is no heteroscedasticity from the equation being tested; (4). Autocorrelation test, it can be seen that the Durbin Watson value is 1.799 and 1.869 between the DU value of 1.770 and 4-DU of 2.230. So it can be stated that the data in this study does not have autocorrelation.

The hypothesis in this study will be tested using path analysis. Path analysis will produce equations in each model. The results of the path analysis test are presented in the following table:

Table 2. Analysis of Path Result

\begin{tabular}{ccccccc}
\hline \multirow{2}{*}{ No } & \multicolumn{2}{c}{$\begin{array}{c}\text { Standardized } \\
\text { Path }\end{array}$} & Beta & Sig & $\boldsymbol{\alpha}$ & Information \\
& X1 & Y1 & 0,318 & 0,003 & 0,05 & Significan \\
2 & X2 & Y1 & 0,104 & 0,344 & 0,05 & insignifican \\
3 & X3 & Y1 & 0,358 & 0,010 & 0,05 & Significan \\
4 & X4 & Y1 & 0,379 & 0,017 & 0,05 & Significan \\
5 & X5 & Y1 & 0,215 & 0,037 & 0,05 & Significan \\
6 & X1 & Y2 & 0,229 & 0,019 & 0,05 & Significan \\
7 & X2 & Y2 & 0,266 & 0,119 & 0,05 & insignifican \\
8 & X3 & Y2 & 0,043 & 0,008 & 0,05 & Significan \\
9 & X4 & Y2 & 0,159 & 0,027 & 0,05 & Significan \\
10 & X5 & Y2 & 0,067 & 0,018 & 0,05 & Significan \\
11 & Y1 & Y2 & 0,322 & 0,017 & 0,05 & Significan \\
\hline
\end{tabular}

Source: Output SPSS, 2020 
Referring to table 1 , it can be explained that the path analysis $1,3,4,5,6,8,9,10$, and 11 have significant results, while lines 2 and 7 have insignificant results. The results of the path analysis can be seen in the following figure:

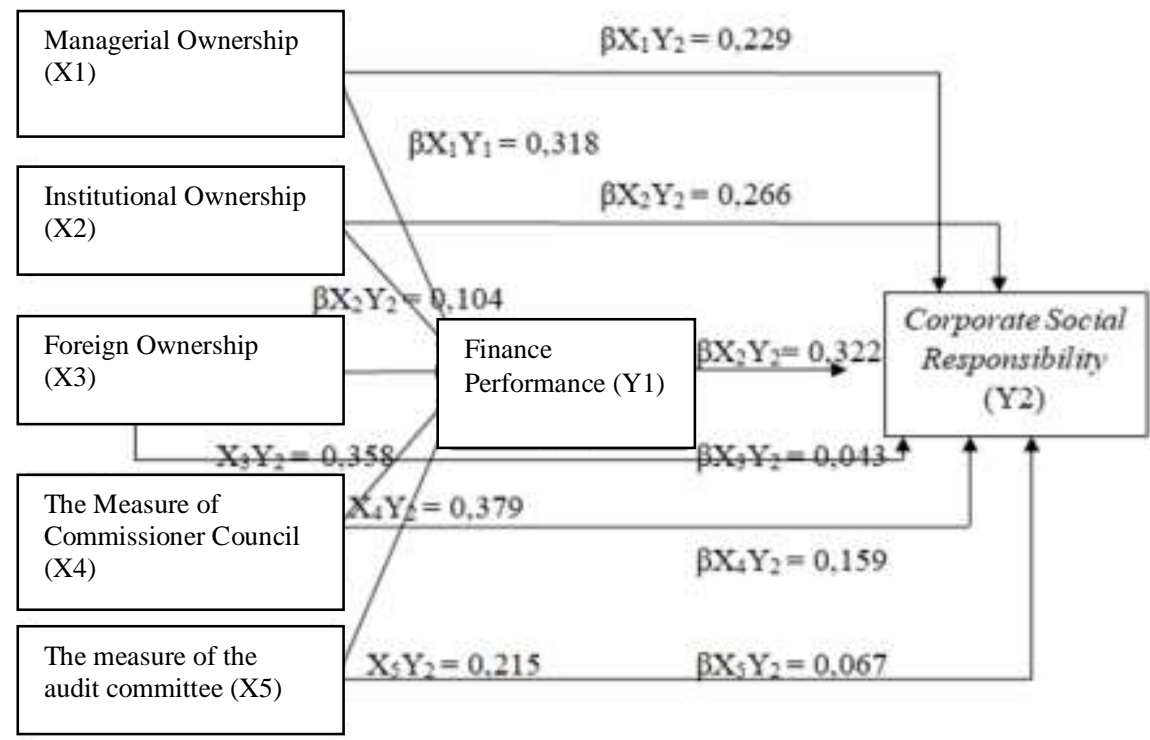

Figure 1. The model of path analysis

Based on the results of the path analysis and the image above, a structural equation can be found: $\mathrm{Y} 1=0.318 \mathrm{X} 1 \mathrm{Y} 1+0.104 \mathrm{X} 2 \mathrm{Y} 1+0.358 \mathrm{X} 3 \mathrm{Y} 1+0.379 \mathrm{X} 4 \mathrm{Y} 1+0.215 \mathrm{X} 5 \mathrm{Y} 1+\mathrm{e}$ (Equation 1$)$ $\mathrm{Y} 2=0.229 \mathrm{X} 1 \mathrm{Y} 2+0.266 \mathrm{X} 2 \mathrm{Y} 2+0.043 \mathrm{X} 3 \mathrm{Y} 2+0.159 \mathrm{X} 4 \mathrm{Y} 2+0.067 \mathrm{X} 5 \mathrm{Y} 2+0.322 \mathrm{Y} 1 \mathrm{Y} 2+\mathrm{e}$ (Equation 2)

Path calculation explains the effect of managerial ownership, institutional ownership, foreign ownership, the board of commissioners size, audit committee on Corporate Social Responsibility through an intervening variable, namely financial performance. Before calculating the path, each path must be tested for its significance. Based on table 2, here are the results of the path coefficient calculation: Indirect Effect :

1) Total effect: $Y \quad X 1 \rightarrow Y_{1} \rightarrow Y_{2}, 0,229+0,102=$ or 0,331 or $33,1 \%$

2) Total effect : $Y \quad X 2 \rightarrow Y_{1} \rightarrow Y_{2}, 0,266+0,033=$ or 0,299 or $22,9 \%$

3) Total effect : $Y \quad X 1 \rightarrow Y_{1} \rightarrow Y_{2}, 0,043+0,115=$ or 0,158 or $15,8 \%$

4) Total effect : $Y \quad X 2 \rightarrow Y_{1} \rightarrow Y_{2}, 0,159+0,122=$ or 0,171 or $17,1 \%$

5) Total effect : $Y \quad X 1 \rightarrow Y_{1} \rightarrow Y_{2}, 0,067+0,069=$ or 0,136 or $13,6 \%$.

Managerial ownership has an effect on financial performance. The test results on the first hypothesis $\left(\mathrm{H}_{1}\right)$ show that managerial ownership affects the company's financial performance with a significant level of 0.003 . The results of the regression coefficient show a positive value, meaning that the higher the managerial ownership, the higher the financial performance $\left(\mathrm{H}_{1}\right.$ is accepted). Based on agency theory, the difference in interests between managers and shareholders results in a conflict, which is commonly known as agency conflict. The conflict of interest between managers and shareholders gets bigger when managerial ownership in the company gets smaller. Conversely, the greater the manager's ownership in the company, the company manager will improve the company's image by disclosing corporate social responsibility (Gray et al., 1995). 
Institutional ownership has no effect on financial performance. The test results on the second hypothesis $\left(\mathrm{H}_{2}\right)$ shows that institutional ownership has no effect on financial performance by looking at the level of significance, which is 0.344 . The results of the regression coefficient show a positive value; it means that the higher the institutional ownership, the financial performance does not change (H2 is rejected). Institutional ownership has no effect on the company's financial performance due to the asymmetry of information between shareholders and managers so that managers as company manager will be able to control the company because they have more information about the company, so it is easier for managers to control the company in making policy. The information which becomes the basis for the institution in conducting supervision is not as good as the information held by management, so that management can exercise control over the company freely. Thus institutional ownership does not have an impact on company performance.

Foreign ownership affects financial performance. The test results on the third hypothesis $\left(\mathrm{H}_{3}\right)$ shows that foreign ownership has an effect on financial performance by looking at the level of significance, which is 0.010 . The results of the regression coefficient show a positive value; it means that the higher the foreign ownership, the financial performance will increase $\left(\mathrm{H}_{3}\right.$ accepted). Agency theory of share ownership is fully owned by shareholders and managers (agents) who are asked to maximize shareholder returns (Hamdani, 2016: 30). The process of forming a good corporate governance system, which plays a role in bridging the separation of interests between owners and managers in carrying out duties and authorities in a company, has a relationship with agency theory. Agency theory provides a new color to the implementation of good corporate governance where the founders of the company can make a balanced agreement between the principal (shareholder) and the agent (director) (Raharjo, 2013).

The Board of commissioners Size effect on financial performance. The results of the t-test on the fourth hypothesis $\left(\mathrm{H}_{4}\right)$ shows that the size of the Board of Commissioners has an effect on financial performance by looking at the level of significance, which is 0.017 . . The results of the regression coefficient show a positive value, meaning that the higher the board of commissioners size, the financial performance will increase $\left(\mathrm{H}_{4}\right.$ accepted). A contract between a manager (agent) and an investor (principal) is an agency relationship described according to agency theory. In agency theory, share ownership is fully owned by shareholders and managers who are asked to maximize investor returns (Hamdani, 2016: 30). Agency costs arise due to a conflict of interest between the owner and the agent because the agent may not always act according to the principal's interests (Hamdani, 2016: 30). According to the KNKG (2004) in Heriyanto (2015), the board of commissioners has the authority to regulate and monitor the highest internal control mechanism and is collectively responsible for supervising and providing input to the board of directors and ensuring that the company implements GCG properly.

The Audit Committee effect toward financial performance. The results of the t-test on the fifth hypothesis $\left(\mathrm{H}_{5}\right)$ shows that the Audit Committee has an effect on financial performance by looking at the level of significance, which is 0.037 . The results of the regression coefficient show a positive value; it means that the higher the Audit Committee, the higher the financial performance $\left(\mathrm{H}_{5}\right.$ accepted). The principals will try to find information and provide intensive efforts to ensure that the agent's responsibility for company ownership is based on agency theory. It is hoped that the audit committee's responsibility for company supervision, financial reporting, and corporate governance is expected to be able to meet the information needs of principals. Based on the information obtained from the audit committee, the principal will measure the level of income obtained from the agent's business. Along with the tight supervision carried out by the audit committee, the company will incur fewer agency costs. 
Managerial ownership affects CSR. The results of the t-test on the sixth hypothesis $\left(\mathrm{H}_{6}\right)$ show that Managerial Ownership has an effect on CSR by looking at the significance level of 0.019. The results of the regression coefficient show a positive value, meaning that the higher the Managerial Ownership, the higher the CSR $\left(\mathrm{H}_{6}\right.$ accepted). Managerial ownership is the shareholder of management who actively participates in decision making (Wahidawati, 2002). Managerial ownership can be measured using the ratio between the number of shares owned by the manager or the board of directors or the board of commissioners to the total shares outstanding (Rustendi \& Jimmi, 2008). Share ownership by managers will encourage the pooling of interests between principals and agents so that agents act in accordance with shareholders' willingness and can improve company performance (Crutchley \& Hansen, 1989). Managerial ownership can reduce agency problems because the manager's performance will be better, along with the increase in share ownership in the company. Managers will try hard to improve company performance.

Institutional ownership has no effect on CSR. The results of the t-test on the seventh hypothesis $\left(\mathrm{H}_{7}\right)$ show that Institutional Ownership has no effect on CSR by looking at the significance level of 0.119 . The results of the regression coefficient show a positive value; it means that the higher the institutional ownership, the $\mathrm{CSR}\left(\mathrm{H}_{7}\right.$ is rejected). Institutional ownership does not significantly influence the CSR disclosure in the annual report. The measurement of institutional ownership in this study uses the percentage of shares owned by institutions, namely the government, banks, foundations, and educational institutions, religions, and other social institutions, which are domestic ownership. The result of the study proved that the level of institutional ownership has no effect on the disclosure of CSR. Companies with a high level of institutional ownership do not necessarily carry out a high level of CSR, and conversely, companies with a low level of institutional ownership do not necessarily carry out a low level of CSR.

Foreign ownership affects CSR. The results of the t-test on the eighth hypothesis $\left(\mathrm{H}_{8}\right)$ shows that foreign ownership affects CSR by looking at the significance level of 0.008 . The results of the regression coefficient show a positive value, meaning that the higher the Foreign Ownership, the higher the CSR $\left(\mathrm{H}_{8}\right.$ is accepted). Foreign share ownership is the number of shares owned by foreign parties (abroad) either by individuals or by institutions or institutions of company shares in Indonesia. Foreign investors are parties who have more attention to CSR disclosure (Sari, 2014: 6). This means that the tendency of foreign investors who invest their shares in Indonesian companies to make better disclosure of social responsibility because of larger ownership of funds and consider this to have an impact on the company's sustainability. In order to maintain legitimacy and a good name, multinational companies have begun to change their behavior in running their businesses. (Fauzi \& Eleven, 2008).

The Board of Commissioners size effect on CSR. The results of the t-test on the ninth hypothesis $\left(\mathrm{H}_{9}\right)$ shows that the board of commissioners size effect toward CSR by looking at the significance level of 0.027 . The results of the regression coefficient show a positive value; it means that the higher the board of commissioners size, the higher the CSR $\left(\mathrm{H}_{9}\right.$ accepted). The bigger the board of commissioners size, the better the ability to supervise company management. Good supervision from the board of commissioners is expected to be able to expand the CSR disclosure report in meeting the information needs of stakeholders. Finally, stakeholders will increasingly support management activities so that they are able to maintain the survival of the limited company.

The Audit Committee effect toward CSR. The results of the t-test on the tenth hypothesis $\left(\mathrm{H}_{10}\right)$ show that the audit committee effect on CSR by looking at the level of significance, which is 0.018 . The results of the regression coefficient show a positive value; it means that the higher the audit committee, the higher the $\mathrm{CSR}$ ( $\mathrm{H}_{10}$ accepted). The audit committee is part of corporate governance; this means that the audit committee is able to provide a role for CSR disclosure. According to Kasmir (2012), the role of the audit committee is to assist the commissioner or supervisory board in ensuring the effectiveness of the internal control system and the implementation of the duties of both internal and external auditors. The company seeks to 
participate in implementing GCG principles as a manifestation of accountability to the community and shareholders.

Financial performance affects CSR. The results of the path analysis in the t-test on the eleventh hypothesis $\left(\mathrm{H}_{11}\right)$ show that there is an effect of financial performance on CSR by looking at the significance level of 0.017 . The relationship shown by the regression coefficient is positive, meaning that the higher the financial performance, the CSR will increase $\left(\mathrm{H}_{11}\right.$ accepted). Profit margin, return on assets (ROA), return on equity (ROE), and dividend payout ratio. This analysis is a method used to measure the level of company profitability. (Kasmir, 2012). If the higher the profitability value, then the possibility of CSR disclosure will also be better. A company is an entity that must be able to share benefits for its stakeholders, not only doing business for personal gain; this is in accordance with stakeholder theory.

Indirect Influence. It shows that financial performance has a mediating effect between managerial ownership and CSR. This means that the higher managerial ownership will encourage the pooling of interests between the principal and the agent so that the agent acts in accordance with the wishes of shareholders and can improve the company's financial performance. Good financial performance is able to encourage companies to properly express CSR. It can be concluded that managerial ownership has an effect on CSR with financial performance as an intervening variable. It shows that financial performance has a mediating effect between institutional ownership and CSR. This means that the higher the level of institutional ownership becomes the driving indicator for the level of disclosure of Corporate Social Responsibility. High financial performance is able to encourage companies to carry out CSR disclosure activities. It can be concluded that institutional ownership has an effect on CSR with financial performance as an intervening variable.

The company's financial performance has a mediating effect between foreign ownership and CSR. This means that the higher the foreign ownership, the company tends to have large funds so that it can improve the company's financial performance. High financial performance is able to encourage companies to CSR disclosure. It can be concluded that foreign ownership affects CSR with financial performance as an intervening variable. It shows that financial performance has a mediating effect between the board of commissioners size and CSR. This means that the larger the size of the board of commissioners, the better the supervision carried out by the company management. Good supervision is expected to improve the company's financial performance. So that when the financial performance is good, it will be able to expand the disclosure of CSR. It can be concluded that the board of commissioners size has an effect on CSR with financial performance as an intervening variable.

The company's financial performance has a mediating effect between the audit committee and CSR. This means that the higher the audit committee, the maximum it will be in assisting the commissioner or supervisory board in ensuring the effectiveness of the internal control system and the implementation of the duties of the internal and external auditors. Good financial performance will be able to expand the disclosure of CSR. It can be concluded that the audit committee has an effect on CSR with financial performance as an intervening variable.

\section{CONCLUSION}

This research aims to analyze the effect of ownership structure and corporate governance on CSR through financial performance. The conclusion is that managerial ownership, foreign ownership, the board of commissioners size, and the audit committee have a positive effect on financial performance. Likewise, the variables of managerial ownership, foreign ownership, the size of the board of commissioners, and the audit committee, and financial performance have an effect on CSR. Meanwhile, institutional ownership has no effect on financial performance and CSR. The 
results of this research indicate that companies that apply a high ownership structure and good corporate governance will be able to improve financial performance and disclosure of good corporate social responsibility.

\section{REFERENCE}

Eriandani, R. (2013). Pengaruh Institutional Ownership dan Managerial Ownership terhadap Pengungkapan CSR pada Laporan Tahunan Perusahaan: Studi Empiris pada Perusahaan Manufaktur 2010-2011. Simposium Nasional Akuntansi XVI. Universitas Negeri Surabaya.

Fahmi, I. (2015). Analisis Laporan Keuangan, Cetakan Kelima. Bandung: Alfabeta.

Fatimah et. al. (2016). Pengaruh komisaris independen dan komite audit terhadap pengungkapan Corporate Social Responsibility perusahaan pertambangan di bursa efek indonesia periode 2012 sd 2014. Jurnal Online Mahasiswa Fakultas Keguruan dan Ilmu Pendidikan Universitas Riau, 3(2), 1-11.

Fauzyyah, R. and Rachmawati S. (2018). The Effect Of Number Of Meetings Of The Board Of Commissioners, Independent Commissioners, Audit Committee And Ownership Structure Upon The Extent Of Csr Disclosure. The Accounting Journal of BINANIAGA, Vol. 03, No. 02.

Ghozali, I. (2013). Aplikasi Analisis Multitative Dengan Program SPSS. Edisi 7. Semarang: Badan Penerbit Universitas Diponegoro.

Ghozali, I. and Anis, C. (2014), Teori Akuntansi, Badan Penerbit Universitas Diponegoro, Semarang.

Hadi, N. (2011). Corporate Social Responsibility. Yogyakarta: Graha Ilmu.

Hamdani. (2016). Good Corporate Governance: Tinjauan Etika dalam Praktik Bisnis. Jakarta: Mitra Wacana Media.

Hastuti. (2016). Pengaruh Karakteristik Perusahaan Manufaktur Terhadap Pengungkapan Corporate Social Responsibility (CSR) Serta Dampaknya Terhadap Reaksi Investor. Seminar Nasional Paper dan The 2nd Call for Syariah Paper-ISSN 2460-0784.

Heriyanto. (2015). Pengaruh Corporate Social Responsibility Terhadap Profitabilitas Perusahaan (Studi Empiris pada Perusahaan Manufaktur yang Terdaftar di Bursa Efek Indonesia Periode 2014-2015). Fakultas Ekonomika dan Bisnis Universitas Diponegoro, Semarang.

Ilmi, M., Kustono, A.S., \& Sayekti, Y. (2017). Effect Of Good Corporate Governance, Corporate Social Responsibility Disclosure And Managerial Ownership To The Corporate Value With Financial Performance As Intervening Variables: Case On Indonesia Stock Exchange. International Journal of Social Science and Business, Vol.1 (2) pp. 75-88.

Indriantoro dan Supomo. (2014). Metodologi Penelitian Bisnis Untuk Akuntansi \& Manajemen. Edisi 1. Cetakan ke-12. Yogyakarta: BPFE.

Kasmir. (2012). Manajemen Perbankan. Edisi revisi 12. Jakarta: PT Raja Grafindo Persada.

Khoirudin, A. (2013). Pengaruh Elemen Good Corporate Governance Terhadap Pengungkapan Corporate Social Responsibility Pada Perbankan Syariah di Indonesia. Artikel Ilmiah Universitas Negeri Semarang.

Listyaningsih, E., Dewi, R. \& Baiti, N. (2018). The Effect of Good Corporate Governance on Corporate Social Responsibility Disclosure on Jakarta Islamic Index. Indonesian Journal of Business and Entrepreneurship, Vol. 4 No. 3.

Othman, R., Thani, A. M., \& Ghani, E. K. (2009). Determinants of Corporate Social Responsibility Among Top Shariah-Approved Companies in Bursa Malaysia. Resarch Journal of International Studies, 12, pg. 4-20.

Riswari, D.A., \& Cahyonowati, N. (2012). Pengaruh Corporate Social Responsibility terhadap Nilai Perusahaan dengan Corporate Governance sebagai Variabel Moderating (Studi pada Perusahaan Publik Non Finansial yang Tercatat di Bursa Efek Indonesia Tahun 20082009). Jurnal Akuntansi, Vol. 1 No. 1. Hal. 1-12. Semarang : UNDIP. 
Sayekti, Y., and Wondabio, L.S. (2007). Pengaruh CSR Disclosure Terhadap Earning Response Coefficient. Simposium Nasional Akuntansi, X:1-35.

Undang-Undang Republik Indonesia Nomor 40 Tahun 2007 Tentang Perseroan Terbatas. https://www.ojk.go.id/sustainable-finance/id/peraturan/undangundang/Documents/5.\%20UU-40-2007\%20PERSEROAN\%20TERBATAS.pdf.

Widyati, M. F. (2013). Pengaruh Dewan Direksi, Komisaris Independen, Komite Audit, Kepemimpinan Manajerial Dan Kepemilikan Institusional Terhadap Kinerja Keuangan. Jurnal Manajemen Fakultas Ekonomi. Universitas Negeri Surabaya. 